\title{
Application of Bleach Concentration Method in Tissue Samples Received for Diagnosis of Extra Pulmonary Tuberculosis Diagnosis
}

Pranali Pingle*

Microbiologist, Medicare Hospital, Indore, India

*Corresponding author: Pranali Pingle, Microbiologist, Medicare Hospital, Indore, India, Tel: 9827096447; E-mail: pranalispingle@yahoo.com

Rec date: June 03, 2014, Acc date: Oct 29, 2014, Pub date: Oct 31, 2014

Copyright: (c) 2014 Pingle P. This is an open-access article distributed under the terms of the Creative Commons Attribution License, which permits unrestricted use, distribution, and reproduction in any medium, provided the original author and source are credited.

\begin{abstract}
Extra pulmonary Tuberculosis (TB) comprises $15 \%$ of the total tuberculosis cases. In cases of suspected extrapulmonary tuberculosis, rapid and accurate laboratory diagnosis is of prime importance, since traditional techniques of detecting acid-fast bacilli have limitations. The major difficulty with mycobacteria in tissue samples is achieving optimal cell lysis. A comparison of two methods, pretreatment of tissue with $4 \%$ Sodium Hypochlorite in Bleach concentration method and pretreatment with petroff's method before culture on Lowenstein Jensen medium, was conducted on 18 extrapulmonary tissue specimens collected from different sites of suspected TB patients to evaluate the use of Bleach concentration method in tissue samples. The aim of this study is to apply this method for demonstration of AFB in tissue samples obtained from extrapulmonary sites and to correlate with Ziehl Neelson staining and LJ culture. A total of 18 tissue samples were studied from clinically suspected cases of Extra pulmonary TB which included endometrial tissue (15), (1) from kidney and (1) from brain. All the samples were processed for conventional ZN staining, bleach concentration method, PCR and AFB culture on LJ media. Out of 18 samples none were suggestive for TB by ZN staining, while $1(5.55 \%)$ was positive by PCR, 3(16.66\%) were suggestive by bleach concentration method and the same i.e. $3(16.66 \%)$ came positive on LJ culture hence confirming the method. However to the best of our knowledge this is the pioneer study applied to the tissue samples and the results of the present study shows improved detection of AFB.
\end{abstract}

Keywords: Extrapulmonary tuberculosis; Bleach concentration method; LJ culture; PCR

\section{Introduction}

Tuberculosis, a leading cause of death, infects more than a third of the world's population [1]. India alone accounted for 2.0-2.5 million cases in 2010, thus contributing approximately $26 \%$ of all TB cases worldwide [2]. EPTB has become more common since the advent of human immunodeficiency virus (HIV) infection [3]. EPTB constitutes about $15-20 \%$ of TB cases and can constitute up to $50 \%$ of TB cases in HIV-infected individuals [4]. Conventional methods for the diagnosis of tuberculosis include smear and culture for Mycobacterium tuberculosis. Ziehl-Neelson staining for acid-fast bacilli requires 104-106 bacilli/ml of tissue or fluid specimens to give a positive result $[5,6]$ Although culture for mycobacterium is more sensitive, it still needs 101-102 bacilli/ml of sample for the diagnostic yield and requires two to four weeks for the growth of $M$. tuberculosis. Diagnosis of tuberculosis from tissue samples is usually made by histopathological examination (HPE) that depends on the presence of granulomatous inflammation and caseous necrosis. It needs high expertise and the final reporting takes more than one week. A diagnostic method that is less time-consuming and at the same time has high sensitivity and specificity is therefore desirable [7]. Advanced molecular methods such as Polymerase Chain Reaction (PCR), a type of nucleic acid amplification system, have shown very promising results for early and rapid diagnosis of the disease due to its detection limit of one to ten bacilli in various clinical samples. IS6110 has been proved to be a good target because of the presence of multiple copies of this insertion sequence (1-20) in most strains of M. tuberculosis complex $[8,9]$. However, few studies from different geographical regions of the world have reported that some clinical isolates have either a single copy or no copy of IS6110 which leads to false negative results [10-12]. Newer molecular techniques, such as polymerase chain reaction (PCR), although rapid; are too costly to be routinely used in the settings where most TB cases occur [10]. The usefulness, priority and scope of various techniques used in TB bacteriology depend on the epidemiological situation prevailing in individual countries and on the resources available. In most low income countries, the only practically available bacteriological method for diagnosing extrapulmonary tuberculosis is direct smear microscopy for AFB of the sample from the lesion. Therefore, there is a need to detect methods for improvement of diagnosis of tuberculosis by techniques that are appropriate in developing countries. Various studies have shown bleach concentration method is cost effective, sensitive, versatile and safe procedure for demonstration of tubercle bacilli and is very valuable in diagnosing case of extra pulmonary tuberculosis [13-16] and would benefit the patients to receive an early and specific treatment. Based on the above literature we have used the bleach concentration method in tissue samples which is in its type the first study. Using tissue samples as a source, the bleach concentration prior to Zeihl-Nelson (ZN) staining was evaluated to see the increase in positivity of $\mathrm{AFB}$ as compared to direct $\mathrm{ZN}$ staining. Further the results were also compared by culture on Lowenstein-Jensen (LJ) media and PCR.

\section{Materials and Methods}

This study was done in the period from August 2012 - December 2013 in Medicare hospital. 
There were 18 samples processed during this period, the samples included endometrium tissue, Kidney tissue and brain tissue suspected for TB. Samples were collected by the doctors in operation theatre in a sterile container having sterile distilled water, and precautions were taken to avoid skin contamination, the samples were kept at $4^{\circ} \mathrm{C}$ before processing. All the tissue biopsies were homogenized in sterile pestle and mortar followed by centrifugation at $6,000 \mathrm{rpm}$ for 10 minutes. The sediment was collected in sterile container, and is then divided into three parts.

The first portion was used for direct $\mathrm{ZN}$ staining and bleach concentration followed by $\mathrm{ZN}$ staining. $\mathrm{ZN}$ staining - ZN staining was performed by conventional method.

Bleach concentration method- It was performed using slight modification of the original method. Sterile, disposable test tubes were used for bleaching. In this approximately $1 \mathrm{ml}$ of the sediment was mixed with $1 \mathrm{ml}$ of commercially available $4 \%$ sodium hypochlorite (merck). After thorough mixing the mixture was incubated for 30 minutes at room temperature with frequent mixing at intervals. An equal volume of commercially available distill water was then added and mixed thoroughly using vortex mixer or disposable sterile plastic pipette and then centrifuged at $3000 \mathrm{~g}$ for 15 minutes. The supernatant was discarded, and smears were prepared using one drop of the sediment, air dried, heat fixed and stained by ZN staining technique. As a control $2 \mathrm{ml}$ of distilled water was centrifuged and the sediment was stained by $\mathrm{ZN}$ staining to rule out any error due to contamination while testing each specimen. After conventional $\mathrm{ZN}$ staining and bleach concentration methods the smears were examined under 100 oil fields for the presence of AFB which is the standard procedure LJ culture- The second portion was used for culture in which the deposits were decontaminated by adding an equal volume of molar sodium hydroxide and mixed for 30 minutes. After centrifugation the sample were neutralized by $8 \% \mathrm{HCl}$ with the help of neutral red and then cultured on LJ slant. PCR- The third portion was used for DNA extraction by Qiagen kit and followed by multiplex PCR for the IS6110 gene specific for $\mathrm{M}$. tuberculosis.

DNA extraction- Tissue which was obtained in sterile saline were only accepted, using gloves and a sharp scalpel blade against the wall of the container the tissue were finely minced. The minced tissue was suspended in $1 \mathrm{ml}$ of sterile distill water in a $1.5 \mathrm{ml}$ vial, and centrifuged at $1000 \mathrm{rpm}$ for $5 \mathrm{~min}$ so that large particles get sedimented. $500 \mu \mathrm{l}$ of the supernatant was taken and centrifuged at $6000 \mathrm{~g}$ for $10 \mathrm{~min}$, the supernatant was decanted and pellet was treated with NALC-NaOH method for the decontamination and liquefaction to obtain the pellet for DNA extraction. (11) The bacterial pellet was resuspended in 180 ul buffer ATL (supplied in QIAamp Tissue Kit, QIAGEN GmbH, Hilden, Germany). The extraction of TB DNA was performed according to QIAGEN kit protocol. The eluted DNA can be stored at $-20^{\circ} \mathrm{C}$ until use in PCR.

PCR assay. The SeeplexR MTB ACE detection uses multitarget (IS6110 and MPB64) and carries out both IS6110 and MPB64 PCR. The PCR mastermix was prepared according to standard protocol of the kit which contained primer pairs, DNA polymerase, buffer containing dNTPs, $\mathrm{MgCl}_{2}$ and stablizersand 8-MOP solution (which prevents carry over contamination). This $15 \mu$ l of mastermix is mixed with $5 \mu$ l of sample's nucleic acid. The PCR conditions for DNA amplification were an initial denaturation step of $94 \mathrm{C}$ for $15 \mathrm{~min}$, followed by 40 cycles of $94 \mathrm{C}$ for $0.5 \mathrm{~min}, 62 \mathrm{C}$ for $1.5 \mathrm{~min}, 72 \mathrm{C}$ for 1.5 $\mathrm{min}$. and a final extension step at $72 \mathrm{C}$ for $10 \mathrm{~min}$. The PCR procedure was accomplished with a thermocycler TC 9600 (Perkin-Elmer Cetus).
After detection step, irradiate UV light $(365 \mathrm{~nm})$ onto PCR product for $20 \mathrm{~min}$ to prevent carry over contamination. Each experiment included positive and negative control tubes. The products of amplification were then analyzed by agarose gel electrophoresis.

\section{Results}

A total of 18 tissue samples were studied. The cases included belonged to the age groups from 24 to 45 . There were 2 males $(11.11 \%)$ and 16 females $(88.89 \%)$. The details of different types of tissue sample are indicated in the Table 1, and about their findings are indicated in Table 2.

\begin{tabular}{|l|l|l|l|}
\hline Method & Samples (tissue) & No. & Percentage \\
\hline Male & kidney & 2 & 11.11 \\
\cline { 2 - 4 } & brain & & \\
\hline Female & Endometrium & 16 & 88.89 \\
\hline Total & & 18 & 100.00 \\
\hline
\end{tabular}

Table 1: Genderwise distribution of Patients (tissue Sample, N=18)

\begin{tabular}{|l|l|l|l|}
\hline Method & Positive & Percentage of positivity & Negative \\
\hline Z-N & 0 & $0 \%$ & 18 \\
\hline TB-PCR & 1 & $5.55 \%$ & 17 \\
\hline AFB culture & 3 & $16.66 \%$ & 15 \\
\hline Bleach method & 3 & $16.66 \%$ & 15 \\
\hline
\end{tabular}

Table 2: Detection by direct methods (tissue Sample, $\mathrm{N}=18$ )

Out of the sample processed, 15 were endometrial tissue 1 was tissue from kidney and 1 was from brain. The smears by conventional ZN staining were negative for all the samples (0\%).

Now when the samples were processed for bleach and then stained by $\mathrm{ZN}$ it detected AFB in 3 samples (16.66\%). Among the 3 bleach positive samples all were positive on AFB culture, 1 was positive by PCR but all were negative by conventional ZN staining.

Except the 3 samples which were positive by bleach method, there were no other samples $(n=3)(16.66 \%)$ which were detected by PCR or AFB culture which is considered to be a gold standard in TB diagnosis.

\section{Discussion}

This study was undertaken to assess the utility of various diagnostic modalities for diagnosis of Extrapulmonary tuberculosis. Also an attempt was made to compare the sensitivity of bleach concentration method with the conventional $\mathrm{ZN}$ staining, and culture. In this study tissue samples from different sites are taken as samples and they are tested by $\mathrm{Zn}$ staining, Bleach concentration method, and LJ culture.

In the present study all the tissue samples were negative by conventional ZN staining which is less as compare to Bhanu et al. [17] and Thangappah et al. [12] which shows $1.3 \%$ and $8.3 \%$ on endometrial samples by ZN staining. Whereas the study done by Ghenaat et al. [18] showed $27.5 \%$ positivity by $\mathrm{ZN}$ stain in lung tissue samples. Reddy et 
al. [19] showed $34 \%$ positivity on paraffin embedded tissue suspected for Extra pulmonary TB.

In the present study, bleach concentration method was positive in $16.66 \%$, there was no study found to compare the bleach concentration method on tissue samples.

With the use of $\mathrm{LJ}$ culture, we could diagnose tuberculosis in $16.66 \%(n=3)$ wheras when compared it was more than the study by Bhanu et al. [17] (3.2\%), Thangappah et al. [12] (5.6\%) and Mani et al. [20] (13.6\%) done on endometrial biopsy. In the study by singh et al. [21] there were $22.7 \%$ of lymphnode aspirates positive on LJ culture.

When PCR was performed on the tissue samples, $5.5 \%(\mathrm{n}=1)$ was positive wheras when compared to Goel et al. [22] (22.2\%), Khanna et al. [23] (26\%), Thangappah et al. [12] (36.7\%), Kohli et al. [24] (13\%) the positive results were lower in this study.

The limitation of this study was that histopathology results were not compared.

\section{Conclusion}

To conclude, bleach method as evidenced by this study forms a cost effective, sensitive, versatile, and safe procedure for demonstration of AFB in tissue samples. On basis of the increased positivity observed by the bleach concentration prior to $\mathrm{ZN}$ staining it can be recommended as an initial step in the diagnosis of TB rather than conventional ZN staining. Until date, none of the available test can pick up all the cases of TB, but use of bleach concentration method with HPE, PCR and LJ will definitely increase the possibility.

\section{References}

1. Onyango RO (2011) State of the Globe: Tracking Tuberculosis is the Test of Time. J Glob Infect Dis 3: 1-3.

2. WHO (2011) The sixteenth global report on Tuberculosis.

3. (2011) World Health Organization Global tuberculosis control. WHO report.

4. Noussair L, Bert F, Leflon-Guibout V, Gayet N, Nicolas-Chanoine MH, et al. (2009) Early Diagnosis of Extrapulmonary Tuberculosis by a New ProcedureCombining Broth Culture and PCR Journal of Clinical Microbiology 47: 1452-1457

5. Cheng VC, Yam WC, Hung IF, Woo PC, Lau SK, et al. (2004) Clinical evaluation of the polymerase chain reaction for the rapid diagnosis of tuberculosis. J Clin Pathol 57: 281-285.

6. Grange JM (1996) The biology of the genus Mycobacterium. Soc Appl Bacteriol Symp Ser 25: 1S-9S.

7. Kiran Chawla, Soham Gupta, Chiranjay Mukhopadhyay, Sugandhi Rao P., Sudha S. Bhat (2009) PCR for M. tuberculosis in tissue samples J Infect Developing Countries 3: 83-87.

8. Hellyer TJ, DesJardin LE, Assaf MK, Bates JH, Cave MD, et al. (1996) Specificity of IS6110-based amplification assays for Mycobacterium tuberculosis complex. J Clin Microbiol 34: 2843-2846.
9. Marchetti G, Gori A, Catozzi L, Vago L, Nebuloni M, Rossi MC, et al. (1998) Evaluation of PCR in Detection of Mycobacterium tuberculosis from Formalin-Fixed, Paraffin Embedded Tissues: Comparison of Four Amplification Assays. J Clin Microbiol 36: 1512-1517.

10. Angeby KA, Hoffner SE, Diwan VK (2004) Should the 'bleach microscopy method' be recommended for improved case detection of tuberculosis? Literature review and key person analysis. Int J Tuberc Lung Dis 8: 806-815.

11. Dale JW, Al-Ghusein H, Al-Hashmi S, Butcher P, Dickens AL, et al. (2003) Evolutionary relationships among strains of Mycobacterium tuberculosis with few copies of IS6110. J Bacteriol 185: 2555-2562.

12. Thangappah RB, Paramasivan CN, Narayanan S (2011) Evaluating PCR, culture \& histopathology in the diagnosis of female genital tuberculosis. Indian J Med Res 134: 40-46.

13. Khubnani H, Munjal K (2005) Application of bleach method in diagnosis of extra-pulmonary tuberculosis. Indian J Pathol Microbiol 48: 546-550.

14. Gangane N, Anshu, Singh R (2008) Role of modified bleach method in staining of acid-fast bacilli in lymph node aspirates. Acta Cytol 52: 325-328.

15. Annam V, Karigoudar MH, Yelikar BR (2009) Improved microscopical detection of acid-fast bacilli by the modified bleach method in lymphnode aspirates. Indian J Pathol Microbiol 52: 349-352.

16. Chandrasekhar B, Prayaga AK (2012) Utility of concentration method by modified bleach technique for the demonstration of acid-fast bacilli in the diagnosis of tuberculous lymphadenopathy. J Cytol 29: 165-168.

17. Bhanu NV, Singh UB, Chakraborty M, Suresh N, Arora J, et al. (2005) Improved diagnostic value of PCR in the diagnosis of female genital tuberculosis leading to infertility. J Med Microbiol 54: 927-931.

18. Ghenaat J, Omidi A, Ghazvini K, Ayatollahi H, Hossein Jafarian A, et al. (2006) Comparison of Multiplex PCR and Acid fast and AuramineRhodamine staining for detection of Mycobacterium tuberculosis and nontuberculosis Mycobacteria in Paraffin- Embedded pleural and bronchial tissues with granulomatous inflammation and caseous necrosis. The Internet Journal of Microbiology 4: 4-7.

19. Reddy S, Brown T, Drobniewski F (2010) Detection of Mycobacterium tuberculosis from paraffin-embedded tissues by INNO-LiPA Rif.TB assay: retrospective analyses of Health Protection Agency National Mycobacterium Reference Laboratory data J Med Microbiol 59: 563-566.

20. Mani R, Nayak S, Kagal A, deshpande S, Dandge N, Bhardwaj R, et al. (2003) Tubercular endometris in infertility: a bacteriological and histopathological study. Indian J Tuberc 50: 161.

21. Singh KK, Muralidhar M, Kumar A, Chattopadhya TK, Kapila K, Singh $\mathrm{Mk}$, et al. (2000) comparison of in house polymerase chain reaction with conventional techniques for detection of Mycobacterium tuberculosis DNA in granulomatous lymphadenopathy. J clin pathol 53: 355-361.

22. Goel G, Khatuja R, Radhakrishnan G, Agarwal R, Agarwal S, et al. (2013) Role of newer methods of diagnosing genital tuberculosis in infertile women. Indian J Pathol Microbiol 56: 155-157.

23. Khanna A, Agrawal A (2011) Markers of genital tuberculosis in infertility. Singapore Med J 52: 864-867.

24. Kohli MD, Nambam B, Trivedi SS, Sherwal BL, Arora S, et al. (2011) PCR-Based Evaluation of Tuberculous Endometritis in Infertile Women of North India. J Reprod Infertil 12: 9-14. 